\title{
Factors associated with absenteeism-illness in rural workers in a timber company ${ }^{1}$
}

\author{
Mariana Roberta Lopes Simões ${ }^{2}$ \\ Adelaide De Mattia Rocha ${ }^{3}$ \\ Carla Souza ${ }^{4}$
}

The monitoring of absenteeism-illness has revealed its high prevalence, and a strong relationship with work. This study aimed to analyze the factors associated with absenteeismillness among the rural workers in a timber company in Minas Gerais, Brazil. It is an analytical cross-sectional study, carried out among 883 workers. The medical certificates issued in the company over one year were surveyed. For the analysis, use was made of descriptive statistics and bi- and multivariable analyses. The strength of association was measured by the odds ratio $(O R)$ with help from logistic regression $(p<0.05)$. A prevalence of $54 \%$ of medical certificates was found in the population. Bivariate analysis revealed an association between job (forestry assistant $(O R=13.1)$, carpenter $(O R=15)$ and chainsaw operator $(\mathrm{OR}=39.6)$, length of service in the company, departments and length of schooling with absenteeism-illness. In the multi-variate analysis, the association between length of schooling and being a carpenter disappeared, while the other associations remained. It is concluded that there is important evidence about the occupational and demographic factors and absenteeism-illness among forestry workers.

Descriptors: Occupational Health; Absenteeism; Rural Workers.

\footnotetext{
${ }^{1}$ Paper extracted from Master's Thesis "Análise do absenteísmo-doença dos trabalhadores rurais de uma empresa florestal" presented to Escola de Enfermagem, Universidade Federal de Minas Gerais, Brazil.

2 MSc, Adjunct Professor, Departamento de Enfermagem, Universidade Federal dos Vales do Jequitinhonha e Mucuri, Brazil.

${ }^{3}$ PhD, Adjunct Professor, Escola de Enfermagem, Universidade Federal de Minas Gerais, Brazil.

${ }^{4}$ Master's student, Faculdade de Ciências Farmacêuticas de Ribeirão Preto, Universidade de São Paulo, Brazil.
}

Corresponding Author:

Mariana Roberta Lopes Simões

Universidade Federal do Vale do Jequitinhonha e Mucuri

Departamento de Enfermagem

Rua da Glória, 187

Centro

CEP: 39100-000, Diamantina, MG, Brasil

E-mail: mari_curvelo@yahoo.com.br 


\title{
Fatores associados ao absenteísmo-doença dos trabalhadores rurais de uma empresa florestal
}

O acompanhamento do absenteísmo-doença tem revelado altas prevalências e forte relação com o trabalho. Objetivou-se analisar os fatores associados ao absenteísmodoença dos trabalhadores rurais de uma empresa florestal em Minas Gerais, Brasil. Tratase de estudo transversal, analítico, realizado com 883 trabalhadores. Foram levantados os atestados médicos desses trabalhadores, durante um ano. Utilizaram-se, para análise estatística descritiva, análises bi e multivariadas. A força de associação foi medida pelo odds ratio $(O R)$ com auxílio da regressão logística $(p<0,05)$. Foi encontrada prevalência de $54,0 \%$ de atestados na população. A análise bivariada revelou associação entre a função (ajudante florestal $(O R=13,1)$, marceneiro $(O R=15)$ e operador de motosserra $(\mathrm{OR}=39,6))$, tempo de trabalho, setores e escolaridade com o absenteísmo-doença. Na análise multivariada houve desaparecimento da associação com o marceneiro e com a escolaridade, sendo mantidas as demais. Conclui-se que há evidências importantes sobre a relação entre fatores ocupacionais e demográficos e o absenteísmo-doença dos trabalhadores florestais.

Descritores: Saúde do Trabalhador; Absenteísmo; Trabalhadores Rurais.

\section{Factores asociados al absentismo-enfermedad de los trabajadores rurales de una empresa forestal}

\begin{abstract}
El acompañamiento del absentismo-enfermedad ha revelado altas prevalencias y fuerte relación con el trabajo. Se objetivó analizar los factores asociados al absentismoenfermedad de los trabajadores rurales de una empresa forestal en Minas Gerais- Brasil. Se trata de un estudio transversal, analítico, realizado con 883 trabajadores. Fueron levantados los testificados médicos durante un año. Se utilizó para análisis estadístico descriptivo, análisis bi y multivariadas. La fuerza de asociación fue medida por el odds ratio $(O R)$ con auxilio de la regresión logística $(p<0,05)$. Fueron encontradas prevalencia del $54,0 \%$ de testificados en la población. El análisis bivariada reveló asociación entre la función (ayudante forestal $(O R=13,1)$, ebanista $(O R=15)$ y operador de motosierra $(\mathrm{OR}=39,6))$, tiempo de trabajo, sectores y escolaridad con el absentismo-enfermedad. En la multivariada hubo desaparición de la asociación con el ebanista y con la escolaridad, siendo mantenidas las demás. Se concluye que hay evidencias importantes sobre la relación entre factores ocupacionales y demográficos y el absentismo-enfermedad de los trabajadores forestales.
\end{abstract}

Descriptores: Salud Laboral; Absentismo; Trabajadores Rurales.

\section{Introduction}

Currently, addressing the theme of health and work in a rural Brazilian environment presents various challenges, principally deriving from the complexity and diversity of work in the sector(1).

The sphere of rural forestry work is constituted as much of maintaining the forest as of removing material from it and transforming it into products ${ }^{(2)}$. It is this diversity - characterized by manual productive processes allied with industrial technology - which makes the sector such an important actor in the building of the new scenario of labor in the Brazilian countryside.

With the increase in demand for timber, principally dating from the 90s, the Brazilian forestry sector has passed through transformations, seeking safer 
and more suitable alternatives for production, which might guarantee economic, environmental and social sustainability ${ }^{(3)}$.

The growth in production of Brazilian forestry companies, and in international demands for the products of this chain, have turned Brazil into one of the largest exporters of forest-derived products. Over the years, the forestry sector has stood out as one of the country's major growth sectors, contributing to the creation of jobs and income ${ }^{(4)}$.

In a general way, the growth of production and technological modernization in the rural environment have meant an intense mobilization of human contingents, however, they have not contributed to the improvement of living or work conditions - on the contrary, the historic exploitation of the work force and the increase in risk factors for workers' health has worsened ${ }^{(5-7)}$.

The risk factors and the workloads give rise, forcibly, to adaptation mechanisms among the workers. These mechanisms occur through the human body's capacity to respond to specific conditions and - when the worker's ability is overcome - result in exhaustion ${ }^{(8)}$.

Besides simply representing illness, the worker's exhaustion may be understood as a loss of the worker's potential and/or effective physical and psychological capacity. Normally, the forms of exhaustion are shaped by the collective actions, defining a pathological profile for the different groups of workers, which characterizes the phenomenon as dynamic, dependent, and historically determined $^{(8)}$.

The process of becoming worn-out may lead the worker to absent himself from his work commitments so as to recover physically or psychologically. The absence of a worker from his working activities is commonly defined in the literature as absenteeism.

Although absenteeism represents the absence of the worker from work, it may be categorized in the following ways: voluntary absenteeism, where the worker misses work for private reasons; legal absenteeism, where missing work is backed by the law, rather like maternity leave; compulsory absenteeism, where the worker misses work as a result of a disciplinary procedure and, lastly, absenteeism-illness, which is due to the worker falling ill; this last being able to be sub-divided into workrelated illnesses, work-related accidents, and illnesses not directly related to the work $^{(9-10)}$. Occurrences of absenteeism-illness are usually granted with medical certificates.
The absences from work from illness are important indicators, as much of health problems as of the causes of losses of productivity and of workers' ability to cope with their work ${ }^{(11)}$. This observation allows one to understand part of the difficulties in obtaining information referent to the reality of workers' health, especially the workers in rural environments in Brazil(12).

The identification of illness through monitoring absenteeism-illness has revealed its high prevalence and its strong relationship with work. Faced with this, the present study is intended to analyze the factors associated with absenteeism-illness among the rural workers in a forestry company in Minas Gerais, by carrying out a survey of the socio-demographic and occupational profile of the workers, and relating it to absenteeism-illness.

\section{Methodology}

This is a cross-sectional and analytical epidemiological study.

This study was developed in a forestry company which manages eucalyptus forest in the central region of Minas Gerais in Brazil.

The company is of great representativeness to the region where it is based. It is dedicated to the production of eucalyptus forests which are destined to be turned into charcoal, craft furniture and chemically-treated wood products.

The work contract is governed by the Brazilian Labor Code (CLT, in Portuguese) with working hours of 44 hours per week.

From the organizational perspective of the company, the sectors existing are:

- Silviculture - practices for cultivating the eucalyptus which are carried out in the forest, in the open air, such as: Preparing, planting and maintaining the forests;

- Logging - activities of manual harvesting, de-limbing (re-cutting the wood), semi-mechanized de-barking and the transporting of the logs. This also takes place in the open air, with the use of chainsaws, cranes and de-barking machines;

- The Wood Treatment Unit (WTU) - where the wood is chemically-treated, under pressure, in an autoclave. The maintenance and organization of the stock, and the dispatch of the treated logs, is also done in this department;

- Carpentry - a small test workshop for furniture, with small-scale production of rustic furniture destined for domestic consumption. 
- Administrative: activities undertaken for the administrative functions of planning, management, supervision and technical support of other departments.

To make it easier to understand this work, some of the jobs existing in the company have been grouped into categories due to their small numbers and the similarity of their activities, while others have been kept separate, being identified by their Brazilian occupation code $(\mathrm{BOC})$, in the following way: administrative category: includes managers, coordinators, supervisors, foremen, administrative assistants and helpers, security, health and social staff, forestry and human resources analysts, who carry out office work, planning or management; drivers (CBO-7823-05); forestry assistants (CBO-632125) a role which involves carrying out activities using physical force at all stages of the process of timber production and in all departments, with the exception of administration; general work assistants (CBO-632615) who carry out activities principally of control and organization of the wood and maintenance services in general; carpenters (CBO- 7711-05) carry out tasks in the small-scale production of furniture, using machines; machine operators (CBO-6420-15) operate machines and agricultural or forestry implements; chainsaw operators (CBO-6321-20); and the category "others" for the remaining jobs with low numbers (from to two workers) such as porters, watchmen and cleaners.

The population studied was made up of 883 workers from all the jobs and from all departments of the company, in activity for some period of the year studied.

For monthly surveying and monitoring of the information relating to the medical certificates, initially a spreadsheet using the Microsoft Office Excel tool (electronic spreadsheet program) was developed, in which the study's variables were addressed. Data collection took place based on an active direct search of the certificates presented by the workers during 12 consecutive months. The other information, not included in the certificates, was sought in secondary databases, such as records in the health or personnel departments of the company, this activity being undertaken exclusively by the researcher. This information was: job, department and length of service, gender, age (in years) and schooling: Illiterates (with no formal years of study), junior school (up to 8 years of study) and secondary school (from 9 to 11 years of study) and over 12 years of study.

The information organized on the spreadsheet was transferred to the statistics program Statistical Package for Social Science (SPSS), version 16.0. The population was characterized according to the variables researched, which consisted of the calculation of prevalences, means and medians. Afterwards, the medical certificates were distributed according to duration of the event, job department, length of service in the company and role; and separated according to the workers' age and gender.

To verify associations between the variables, initially a bivariate analysis with a Chi-square test was carried out. The strength of association was measured by the Odds Ratio (OR) and calculated with the aid of the technique of logistic regression. In these analyses, the level of statistical significance established was $5 \%$ $(p<0.05)$. This was followed by multi-variate analysis by unconditional logistic regression, also with a level of significance of $5 \%(p<0.05)$.

This research was approved by the Research Ethics Committee of the Federal University of Minas Gerais (COEP, in Portuguese) under Approval Protocol no ETIC $379 / 08$.

\section{Results}

The study group was made up of 883 workers, with a monthly average of 560 workers. This population's distribution, according to socio-demographic and occupational characteristics, is shown in Figure 1. 


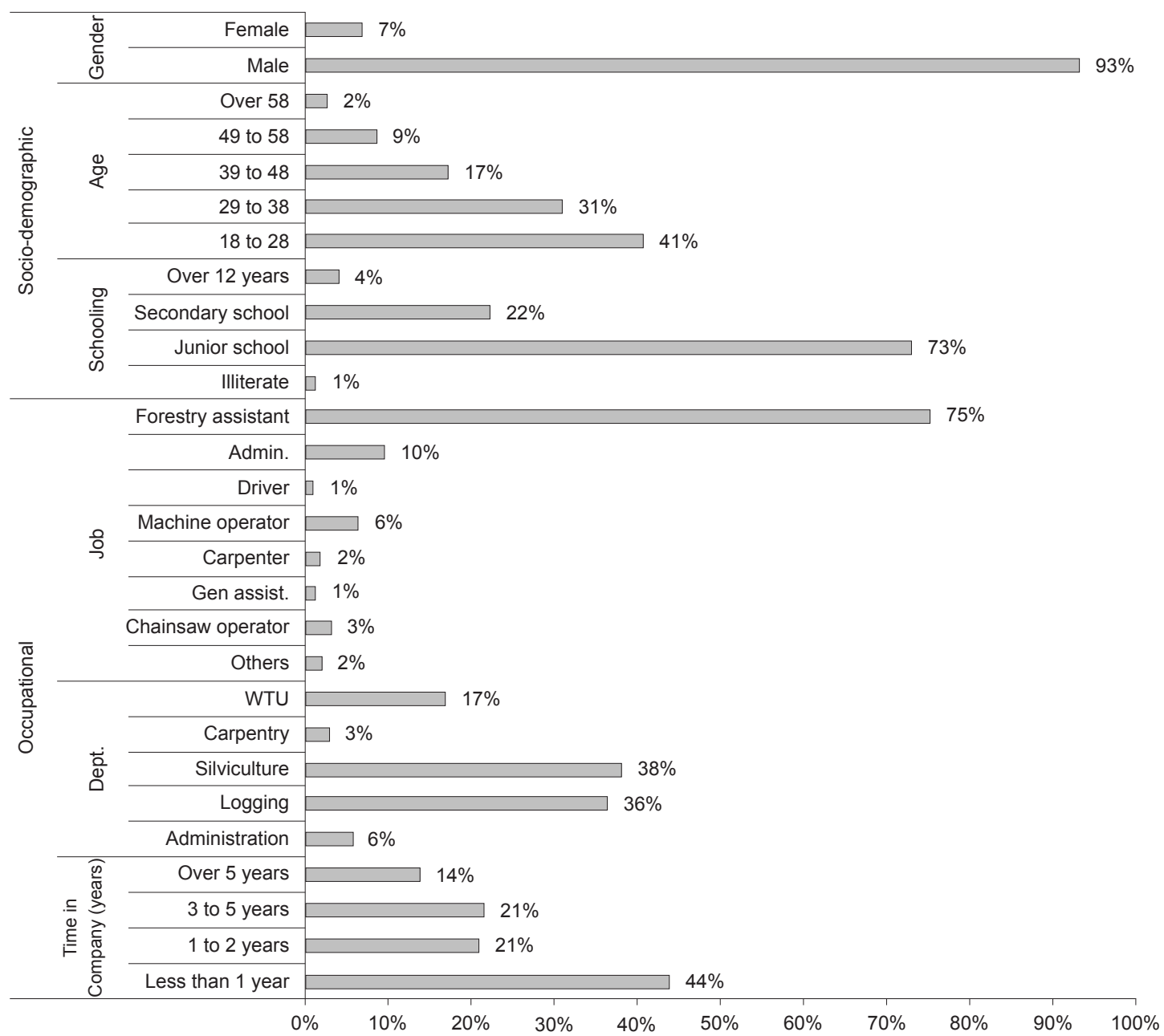

Figure 1 - Distribution of the population of forestry workers, according to socio-demographic and occupational characteristics. Minas Gerais, Brazil, 2009

In the period studied, $54 \%$ of the population had one or more medical certificates issued, accounting for 2,047 medical certificates and 7,655 days lost. The prevalences of medical certificates, depending on the socio-demographic variables, kept at between 40 and $60 \%$, with the exception of the level of schooling over 12 years $(17 \%)$. There was a decreasing tendency in prevalence with increase in age, of $60 \%$ between those from 18 to 28 years of age, and $41 \%$ in the category of over 58 years of age. The prevalence of certificates among women (61\%) was greater than among the men (53\%).

The bi-variate analysis revealed that the behavior of absenteeism-illness was not associated with the factors of age and gender. However, there was evidence of a significant association $(p<0.05)$ with the other factors, such as role, department, length of service with the company and schooling (Table 1 ).

Table 1 - Prevalence, Odds ratio (OR) and Confidence Interval (CI95\%) for medical certificates, according to sociodemographic and occupational characteristics of forestry workers. Minas Gerais, Brazil, 2009

\begin{tabular}{lcccccc}
\hline \multicolumn{1}{c}{ Variable } & $\mathbf{N}^{*}$ & $\mathbf{n}^{\dagger}$ & Prevalence (\%) & OR & Cl (95\%) & P-value \\
\hline Sex & & & & & & \\
Male & 822 & 437 & 53.16 & 1 & - & 0.259 \\
Female & 61 & 37 & 60.66 & 1.36 & $0.80-2.31$ &
\end{tabular}


Table 1 - (continuation)

\begin{tabular}{|c|c|c|c|c|c|c|}
\hline Variable & $\mathbf{N}^{*}$ & $n^{\dagger}$ & Prevalence (\%) & OR & $\mathrm{Cl}(95 \%)$ & P-value \\
\hline \multicolumn{7}{|l|}{ Occupation } \\
\hline Driver & 10 & 1 & 10 & 1 & - & \\
\hline Administrator & 84 & 18 & 21.43 & 2.46 & $0.29-20.67$ & 0.409 \\
\hline Forestry assistant & 663 & 393 & 59.28 & 13.1 & $1.65-104.00$ & 0.015 \\
\hline Gen. Work assistant & 10 & 4 & 40 & 6 & $0.53-67.65$ & 0.147 \\
\hline Carpenter & 16 & 10 & 62.5 & 15 & $1.50-149.70$ & 0.021 \\
\hline Machine operator & 56 & 22 & 39.29 & 5.8 & $0.68-49.22$ & 0.106 \\
\hline Chainsaw operator & 27 & 22 & 81.48 & 39.6 & $4.04-388.23$ & 0.002 \\
\hline Others & 17 & 4 & 23.53 & 2.7 & $0.26-29.05$ & 0.396 \\
\hline \multicolumn{7}{|l|}{ Age (years) } \\
\hline From 18 to 28 & 359 & 215 & 59.89 & 1.24 & $0.53-2.94$ & 0.62 \\
\hline 28 to 38 & 273 & 139 & 50.92 & 1.16 & $0.49-2.76$ & 0.74 \\
\hline 38 to 48 & 152 & 76 & 50 & 0.99 & $0.40-2.41$ & 0.977 \\
\hline 48 to 58 & 77 & 35 & 45.45 & 1.2 & $0.46-3.1$ & 0.706 \\
\hline Over 58 & 22 & 9 & 40.91 & 1 & - & \\
\hline \multicolumn{7}{|l|}{ Department } \\
\hline Administration & 51 & 8 & 15.69 & 1 & - & \\
\hline Logging & 321 & 189 & 58.88 & 7.7 & $3.50-16.90$ & 0 \\
\hline Silviculture & 336 & 159 & 47.32 & 4.82 & $2.204-10.58$ & 0 \\
\hline Carpentry & 26 & 19 & 73.08 & 14.59 & $4.62-46.03$ & 0 \\
\hline WTU & 149 & 99 & 66.44 & 10.64 & $4.65-24.35$ & 0 \\
\hline \multicolumn{7}{|l|}{ Time in the company } \\
\hline Less than 1 year & 387 & 168 & 43.41 & 1.11 & $0,74-1.67$ & 0.622 \\
\hline Between 1 and 2 years & 185 & 133 & 71.89 & 2.71 & $1.69-4.35$ & 0 \\
\hline Between 2 and 5 years & 189 & 120 & 63.49 & 2.16 & $1.36-3.44$ & 0.001 \\
\hline Over 5 years & 122 & 53 & 43.44 & 1 & - & \\
\hline \multicolumn{7}{|l|}{ Schooling } \\
\hline Illiterate & 10 & 6 & 60 & 7.25 & $1.55-33.84$ & 0.012 \\
\hline Junior school & 641 & 354 & 55.23 & 5.96 & $2.44-14.56$ & 0 \\
\hline Secondary school & 197 & 108 & 54.82 & 5.86 & $2.33-14.76$ & 0 \\
\hline$>12$ years of study & 35 & 6 & 17.14 & 1 & - & 0 \\
\hline
\end{tabular}

NB: $*=$ Total population of the study, equal to 883 in each variable; $+=$ Population with certificates, equal to 474 in each variable.

After adjusting for the five variables significant for $p<0.2$, the analysis presented the disappearance of the association of occurrence medical certificates with the role of carpenter and with schooling; maintaining the association with the roles of forestry assistant and chainsaw operator, with the carpentry and WTU departments, and with variable length of service with the company.

In relation to the cause given, or diagnosis referred to in the medical certificate, what stood out were musculoskeletal illnesses with $23.5 \%$ of the occurrences, followed by respiratory illnesses in $14 \%$ of the certificates.

\section{Discussion}

The profile presented by the population in the study is corroborated by other studies on rural work, in the agricultural and extractive sector ${ }^{(13)}$; with the sugarcane industry ${ }^{(14)}$; with people who work in logging and charcoal production ${ }^{(3,15)}$. All of these studies identified a masculine prevalence, low levels of schooling, and an age range of 18 to 38 years. Evidence was shown for high job turnover, characterized by short links with the company, less than 12 months, which is confirmed by other studies ${ }^{(3,13)}$.

The prevalence of medical certificates was of $54 \%$, that is to say, more than half of the workers presented at least one medical certificate in the year. This reality is also surveyed in another study of logging workers, in which a prevalence of medical certificates of $61 \%$ was found(3).

The statistical analyses made it possible to identify important associations between the occurrence of absenteeism-illness and the variables: job, length of service in the company, and department worked in.

With relation to length of service in the company, the analyses showed evidence of a positive association 
between the occurrence of medical certificates and service-length of between one and two years, suggesting a risk category for the event. There was also evidence for a smaller concentration of certificates among workers who had been with the company for less than a year and among those with service-length of over five years.

The low prevalence of certificates among the workers who had spent little time with the company may be related to questions of insecurity or a greater need to keep the job among these persons.

On the other hand, possible consequences of the work on the workers' health may require different times to become apparent - and these may not be easily estimated. The association found provides indications of a relationship which deserves better investigation. The careful evaluation of the length of exposure to the workloads is a fundamental factor for establishing a supposed relationship between a labor activity and a health hazard.

Concerning the 'job' variable, the jobs of chainsaw operator and forestry assistant were positively associated with absenteeism-illness, even after adjustment for other variables studied.

The occurrence of medical certificates among the chainsaw operators may be attributed to the extreme physical demands of the activity. The undertaking of repetitive movements with the upper limbs, carrying of weight, inappropriate posture, vibration and organization of work by tasks are indicated as factors for overwork in the activity ${ }^{(3)}$. The cumulative effects of physical overload are reflected principally in health hazards related to the musculoskeletal system(3).

In the role of forestry assistant (the majority of the population), what stands out is manual work, low levels of qualifications, a routine of movement and lifting weight and the proximity of risk factors linked with forestry work.

In the forestry sector, the manual handling of loads represents one of the most important ergonomic problems, responsible for injuries which incapacitate the worker and which generally require treatment and time for rehabilitation ${ }^{(3)}$.

The high physical demands of forestry work are also associated with the occurrence of medical certificates in other studies, such as that carried out in Guanhães, Minas Gerais ${ }^{(3)}$.

In both roles (chainsaw operators and forestry assistants), it can be observed that physical demands produce a work environment which is hostile to health.
Among the company 's departments, carpentry and the WTU were positively associated with the occurrence of medical certificates. In general terms, both are characterized as areas where wood is processed. As such, they have work processes which, to a certain degree, are different from the other departments, principally in that they deal with technology.

The workers' health is related to their type of professional activity, to the conditions in which the latter is carried out, the division and organization of work, the content of the tasks, the relationships of power and supervision, and others(16-17). This conclusion explains the differentness of each department, although they all belong to the same organization.

Work in a carpentry area is described as extremely dangerous and exhausting, with a high incidence of work-related accidents and illnesses. The dangers to the health of workers in carpentry arise principally from the desire for productivity. The coexistence of risk factors such as potentially dangerous machines, noise, sawdust, and the fumes from the chemicals used in treating wood, allied with the misuse or non-use of protective equipment in this activity, also stands out ${ }^{(18-19)}$.

As it is an experimental facility, the carpentry unit studied is located within the physical limits of the WTU, and has a small production run. Thus, the workers involved in treating wood, and the workers in the carpentry area studied, share both risks and organizational characteristics of work environments.

In addition to this, the two departments stand out because of the technological interface, in which the activities - which have a high level of human physical demands - are carried out alongside the operation of heavy, dangerous machines with a high capacity for transformation.

Concerning the most prevalent illnesses, those of the musculoskeletal system stood out most in the population. This issue is frequently related to technological gaps, to tasks which require great physical strength, carried out by the workers who undertake manual work ${ }^{(8)}$. In forestry activities, the musculoskeletal system is compromised by the lifting and transporting of loads whose weight is above tolerable limits, with incorrect movements and inappropriate posture(20-21). Besides this, the intense rhythm associated with chasing productivity and the absence of work breaks is a factor which, when present in the rural work environment, contributes to the appearance of musculoskeletal illnesses ${ }^{(6)}$.

After the musculoskeletal system, it is the respiratory system which stands out, responsible for 292 medical 
certificates. Some studies identify the environmental conditions of rural work, in particular the dusts arising from organic and mineral sources, as associated with the increase in the prevalence of respiratory illnesses among the workers ${ }^{(6,14)}$. As well as this, hazards such as upper respiratory tract infections and colds may be strengthened by the low ingestion of liquids in forest environments, by the hot, dry climate of the region studied and by the presence of sawdust ejected in the processes involved in dealing with eucalyptus wood.

The results indicate the need for a specific evaluation of the conditions and work relations which give rise to the disparities referent to absenteeismillness among individuals, departments and roles within the organization. It should be emphasized that this issue must be understood in the perspective of workloads, recognized as a set made up of external elements (physical, chemical, mechanical and biological) and internal ones (physiological and psychiatric) present in the work environments and conditions, which interact with human beings, being able to create or not specific patterns of exhaustion ${ }^{(8)}$. This dynamic interaction, in which the various loads are augmented even by individual characteristics, determines the multicausal nature of absenteeism-illness, making it a complex issue.

\section{Conclusion}

Generally speaking, the profile surveyed is made up of young, male workers with low levels of schooling.

In terms of occupational characteristics, what most stood out were high turnover and the job of forestry assistant, which is the most closely related to the manual activities of the process of rural work.

In relation to absenteeism-illness, it was possible to visualize the massive loss of work-days as documented by the medical certificates in the population studied.

The findings also provided important evidence about the relationship between occupational factors and absenteeism-illness among forestry workers.

The following were associated positively with absenteeism-illness among the population studied: Length of service of between one and two years; the roles of forestry assistants and chainsaw operators; and work department, with carpentry and the Wood Treatment Unit standing out, both representing the process of transformation of the wood.

The present study, by dealing with medical certificates, indicators in the study of absenteeism- illness, did not intend to delineate either health as the mere absence of illness, or illness as the only representation of workers' exhaustion. Such an attitude would signify a reversal in the process of knowledge production and would deny the dynamic of the healthwork relationship. However, what was aimed for with this classical approach was to identify relevant associations in health-work-illness in the workplace in a forest environment, with a view to fostering new investigations and new perspectives concerning these workers, so far unexplored in this aspect.

Considering the limitations and possibilities to be gained from attaining the objectives of this research, it has to be considered that the identification of the variables associated with absenteeism-illness of the workers represents a great advance in understanding the health-work-illness relationship in the forest environment. Although these relationships do not necessarily signify a causal relationship, they represent important factors in the process of falling ill, and need further investigation, with a view to contributing to improvements in the processes and conditions of work in the Brazilian forest environment.

\section{References}

1. Alessi NP, Navarro VL. Saúde e trabalho rural: o caso dos trabalhadores da cultura canavieira na região de Ribeirão Preto, São Paulo, Brasil. Cad Saúde Pública. 1997;13(sup2):111-21.

2. Poschen P. Forestry, a safe and healthy profession? Unasylva. 1993;44(172):3-12.

3. Silva EP, Minette LJ, Souza AP, Baêta FC, Fernandes HC, Mafra SCT, et al. Caracterização da saúde dos trabalhadores florestais envolvidos na extração de madeira em regiões montanhosas. Rev Árvore. 2009;33(6):1196-74.

4. Valverde $S R$, Soares NS, Silva ML, Jacovine LAG, Neiva SA. O comportamento do mercado de madeira de eucalipto no Brasil. Rev Biomassa \& Energia. 2004;1(4):393-403.

5. Peres F. Saúde, trabalho e ambiente no meio rural brasileiro. Ciênc. Saúde Coletiva. 2009;14(6):1995-2004. 6. Silva JM, Nonato-Silva E, Faria HP, Pinheiro TMM. Agrotóxico e trabalho: uma combinação perigosa para a saúde do trabalhador rural. Ciênc Saúde Coletiva. 2005;10(4):891-903.

7. Silva JG, Grossi MD, Campanhola C. O que há de realmente novo no rural brasileiro. Cad Ciênc Tecnol. 2002;19(1):37-67. 
8. Laurell AC, Noriega M. Processo de produção e saúde: trabalho e desgaste operário. São Paulo: Hucitec; 1989. $333 \mathrm{p}$.

9. Quick TC, Lapertosa JB. Análise do absenteísmo em usina siderúrgica. Rev Bras Saúde Ocup. $1982 ; 10(40): 62-7$.

10. Sala A, Carro ARL, Correa NA, Seixas PHD. Licenças médicas entre trabalhadores da Secretaria de Estado da Saúde de São Paulo no ano de 2004. Cad Saúde Pública. 2009;25(10):2168-78.

11. North F, Syme SL, Feeney AJ, Shirpley MJ, Marmot MG. Explaining socieconomic differences in sickness absence: the Whitehall II study. $\mathrm{Br}$ Med $\mathrm{J}$. 1993;306(6874):361-6.

12. Dias EC. Saúde do Trabalhador Rural. In: Pinheiro TM, organizador. Condições de vida, trabalho, saúde e doença dos trabalhadores rurais no Brasil. Belo Horizonte; 2006. p. 1-25.

13. Andrietta AJ. Evolução do perfil dos trabalhadores da agropecuária paulista de 1985 à 2002. Inform Econômicas. 2004;34(9):7-19.

14. Rocha FLR, Marziale MHP, Robazzi MLC. Poverty as a predisposing factor of illness tendencies in sugar cane workers. Rev. Latino-Am. Enfermagem. 2007;15(n. spe):736-41.

15. Pimenta AS, Minette LJ, Faria MM, Souza AP, Vital BR, Gomes JM. Avaliação do perfil de trabalhadores e de condições ergonômicas na atividade de produção de carvão vegetal em bateria de fornos de superfície do tipo "rabo-quente". Rev Árvore. 2006;30(5):779-85.

16. Silva DMPP, Marziale MHP. Condições de trabalho versus absenteísmo-doença no trabalho de enfermagem. Ciênc Cuidado Saúde. 2006;5(sup):166-72.

17. Becke SG, Oliveira MLC. Study on the absenteeism of nursing professionals in a psychiatric center in Manaus, Brazil. Rev. Latino-Am. Enfermagem. 2008;16(1):110-4.

18. Pignati WA, Machado JMH. Riscos e agravos à saúde e a vida dos trabalhadores das indústrias madeireiras de Mato Grosso. Ciênc Saúde Coletiva. 2005;10(4):961-73. 19. Silva KR, Souza AP, Minetti LJ. Avaliação do perfil de trabalhadores e das condições de trabalho em marcenarias no município de Viçosa-MG. Rev Árvore. 2002;26(6):769-75.

20. Fernandes RCP, Carvalho FM, Assunção AA, Silvany AM Neto. Interactions between physical and psychosocial demands of work associated to low back pain. Rev Saúde Pública. 2009;43(2):326-34.
21. Picoloto D, Silveira E. Prevalência de sintomas osteomusculares e fatores associados em trabalhadores de uma indústria metalúrgica de Canoas - RS. Ciênc Saúde Coletiva. 2008;13(2):507-16. 